\title{
Acute Raillietiniasis in Domestic Pigeon (Columba livia domestica)
}

\author{
Mustafa Kamal ${ }^{*}$, Wali Khan ${ }^{2}$, Noor Un Nisa ${ }^{3}$, Ghazala Yasmeen ${ }^{1}$, Habib Ul Hassan ${ }^{1}$, \\ IHSANULLAH $^{1}$
}

${ }^{1}$ Department of Zoology, University of Karachi, Karachi-75270, Pakistan; ${ }^{2}$ Department of Zoology, University of Malakand, Khyber Pakbtunkbwa, Pakistan; ${ }^{3}$ Vertebrate Pest Control Institute, PARC-Southern Zone Agricultural Research Centre, Karachi University Campus, Karachi-75270, Pakistan.

\begin{abstract}
Pigeons are infected with many endo and ecto parasites. Raillietina spp. is the most prevalent parasite of pigeons. An adult male pigeon was brought to the laboratory of Parasitology, University of Malakand with clinical signs of diarrhea, emaciation and droopiness. After dissection 223 Raillietina tapeworms were recovered from the small and large intestine. The digestive tract was fully obstructed by these parasites. The intestine was thickened due to high number of parasites and mucus exudate. Hemorrhage was noted in the intestine at different points. Further studies are required to know the prevalence and zoonotic importance of this tapeworm.
\end{abstract}

Keywords | Pigeon, Raillietiniasis, Raillietina spp., Tapeworm, Hemorrhage

Received | June 19, 2020; Accepted | August 15, 2020; Published | September 01, 2020

*Correspondence | Mustafa Kamal, Department of Zoology, University of Karachi, Karachi-75270, Pakistan; Email: mustafakamaluok@gmail.com

Citation | Kamal M, Khan W, Nisa NU, Yasmeen G, Hassan HU, Ihsanullah (2020). Acute raillietiniasis in domestic pigeon (Columba livia domestica). Adv. Anim. Vet. Sci. 8(11): 1180-1183.

DOI | http://dx.doi.org/10.17582/journal.aavs/2020/8.11.1180.1183

ISSN (Online) | 2307-8316; ISSN (Print) | 2309-3331

Copyright (c) $2020 \mathrm{Kamal}$ et al. This is an open access article distributed under the Creative Commons Attribution License, which permits unrestricted use, distribution, and reproduction in any medium, provided the original work is properly cited.

\section{INTRODUCTION}

$\mathrm{P}$ igeon host numerous endo and ecto parasites, such as nematodes, cestodes and single-cell protozoa (Alkharigy et al., 2018; El-Dakhly et al., 2019). Helminths infection shows serious host tissue damage (Hoste, 2001). Diseases like coccidiosis, histoplasmosis, cryptococcosis, encephalitis, newcastle disease, toxoplasmosis and salmonella food poisoning may occur in pigeons (Bahrami et al., 2015). Pigeons may carry mites, ticks, fleas and other parasites as well (Ramisz et al., 2007).

Raillietina spp. is the most prevalent parasite of the pigeons (Adang et al., 2008). The acute condition results in emaciation, diarrhea, droopiness, anemia and hemorrhage in the intestine. Physiological symptoms include enteritis, epithelial cell degeneration and lymphocyte macrophage infiltration (Kaufmann, 1996).

Among cestodes, Raillietina spp. (Fuhrmann, 1920) is the most common, with approximately 295 species reported from avian and mammalian hosts including humans
(Schmidt, 1986). Raillietina spp. are found in the definitive host's ileum and jejunum and cause weakness, emaciation, decreased growth and digestive tract obstruction, however their larval stage (cysticercoid) is found in various invertebrate intermediate host, such as beetle, small mini wasps, ants and termites (Alenyorege et al., 2011; Butboonchoo et al., 2016).

\section{MATERIALS AND METHODS}

An adult male pigeon was collected from a homestead in Chakdara Lower Dir and brought to the laboratory of Parasitology, University of Malakand. Clinical signs show emaciation, diarrhea and droopiness. The pigeon was placed in a vacuum chamber for 6 to 7 minutes containing cotton wool soaked with $10 \mathrm{ml}$ of chloroform. It was then dissected and the digestive tract was removed. The small and large intestine was cut longitudinally and the intestinal contents were taken out. This study was performed following the international guiding principles for biomedical research involving animals and permission was taken from the animal ethics committee of the University of Malakand. 
The tapeworms were collected and then counted. The tapeworms were preserved in 10\% formalin and stained with borax carmine, dehydrated with various alcohol grades, rinsed with xylene and permanently mounted in canada balsam. The prepared slides were examined under the light microscope and identified according to the keys provided by (Soulsby, 1982; Cheng, 1973; Ruprah et al., 1986). The drawings were made with the help of camera Lucida, and all the measurements are calculated in millimeter. The prepared slides were labelled and deposited to the Parasitology Laboratory in the Department of Zoology, University of Malakand.

\section{RESULTS AND DISCUSSION}

A total of 223 cestode parasites were collected and identified as Raillietina spp. (Fuhrmann, 1920). The intestine of the pigeon was fully blocked by the abundance of Raillietina spp. parasites (Figures 1 and 2). The intestine was thickened due to a high number of endo parasites and mucus exudate. Hemorrhage was noted in the intestine at different points (Figure 3 ).

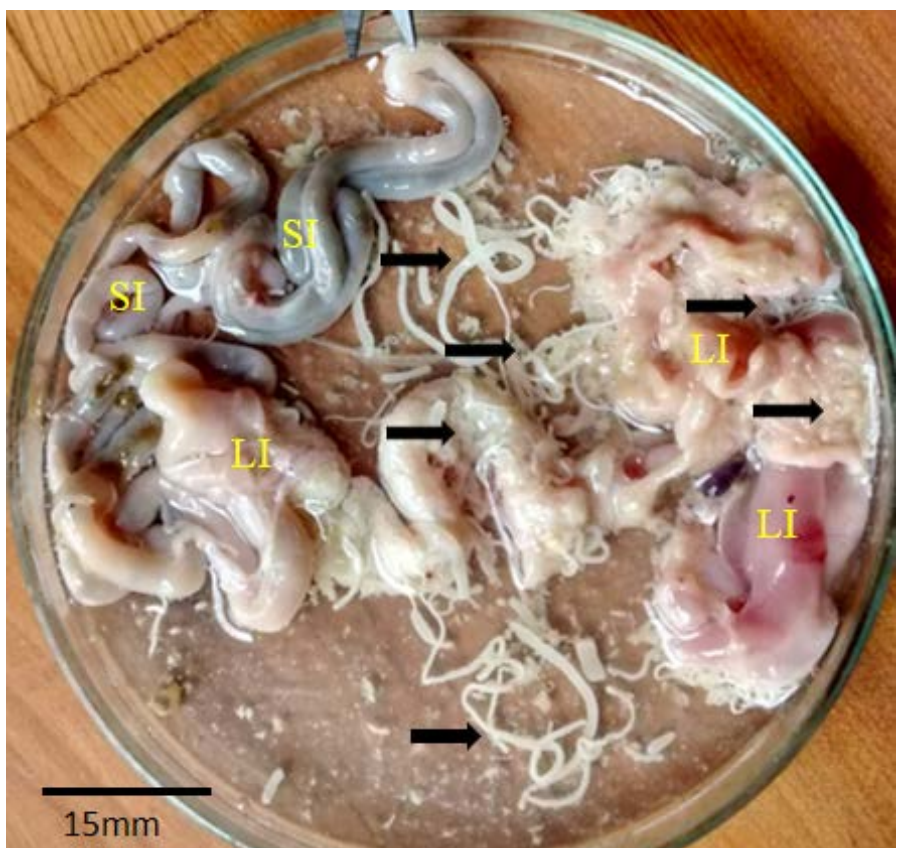

Figure 1: Pigeon intestine with abundance of Raillietina spp. SI: Small intestine; LI: Large intestine; Arrows: Raillietina spp.

The total body size of Raillietina spp. ranges from $17.65 \mathrm{~mm}$ to $29.80 \mathrm{~mm}$ by $0.4 \mathrm{~mm}$ to $0.56 \mathrm{~mm}$. Scolex simple, broader than long. Rostellum with a row of minute hammershaped hooks. Sucker simple. Neck apparently not obvious. Immature, mature and gravid segments broader than long. Ovary bilobed, vitellaria compact, post ovarian, rounded. Testes rounded, surrounded by ovary and vitellaria. Cirrus sac unilateral slightly on the anterior region of the segment. Vagina posterior to the cirrus sac. Gravid segments are also much broader than the mature segments. The uterus breaks into egg capsules each containing several eggs (Figures 4 and 5).

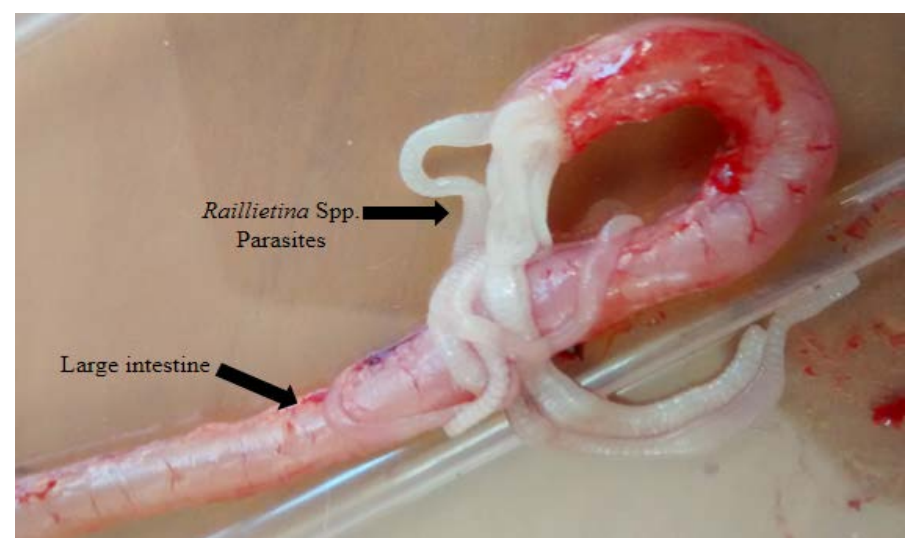

Figure 2: Pigeon large intestine blocked with abundance of Raillietina spp.

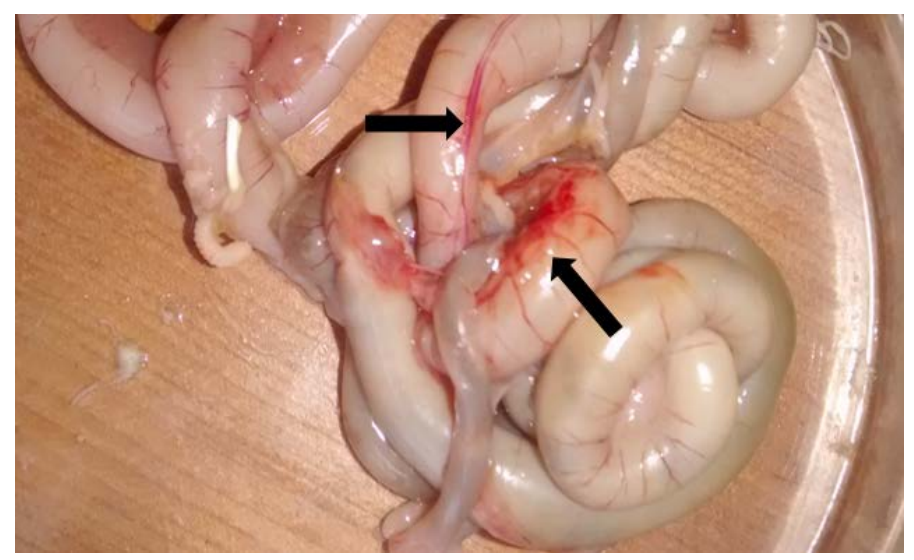

Figure 3: Thickened intestine clearly showing hemorrhage (arrows) at different point.
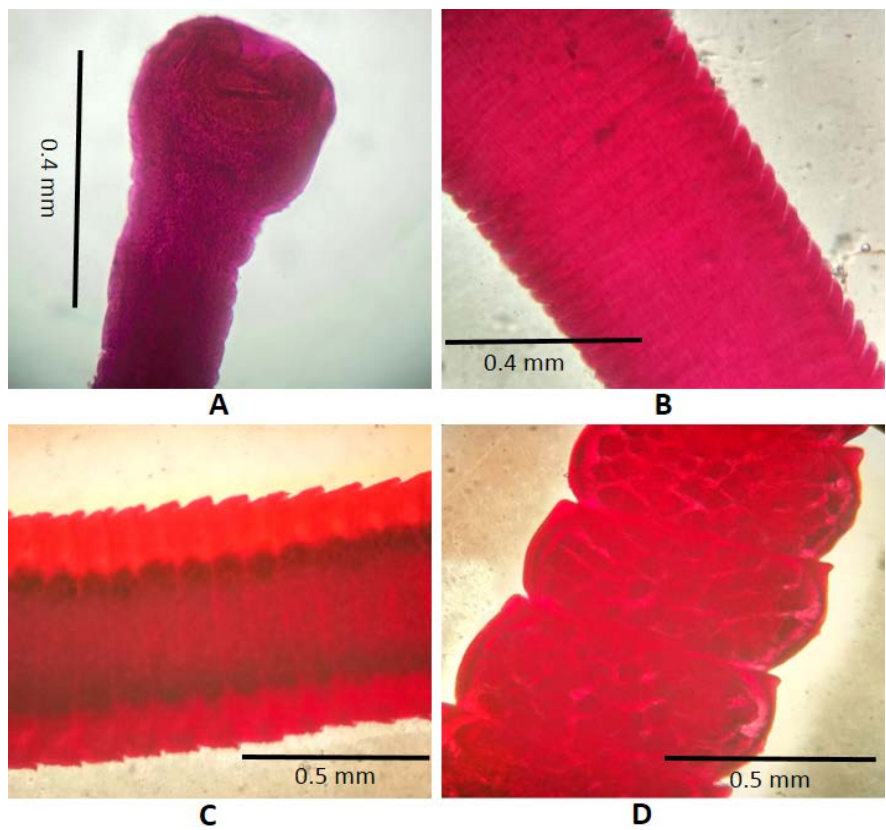

Figure 4: Raillietina spp. (Fuhrmann, 1920). A: Scolex; B: Immature proglottids; C: Mature proglottids; D: Gravid proglottids occupied by uterine eggs. 


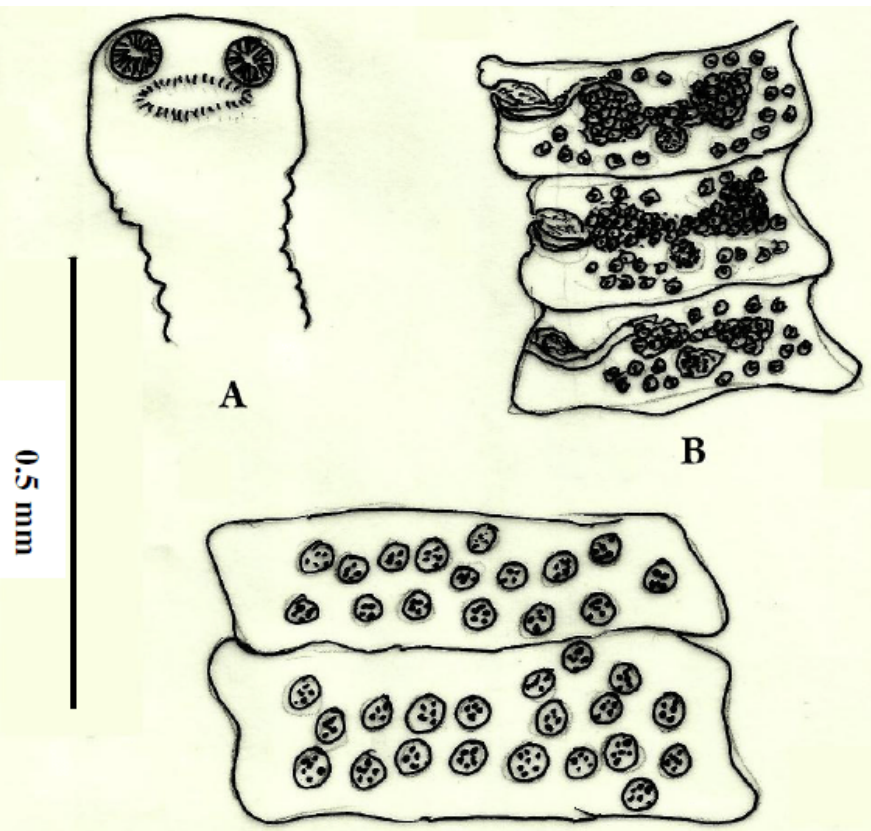

C

Figure 5: Raillietina spp. (Fuhrmann, 1920). A- Scolex showing suckers and rostellum armed; B- Mature proglottids representing the reproductive organs and the position of cirrus sac; C- Gravid segments occupied by uterine eggs.

Such a high number of Raillietina spp. was reported for the first time in a pigeon. Khan et al. (2018) studied the prevalence of ecto and endo parasites of pigeon in Malakand, Pakistan and concluded that Raillietina spp. is the most prevalent parasite by infecting $60 \%$ of the studied pigeons. Shaikh et al. (2016) examined histopathological changes in the intestines of pigeon caused by Raillietina tetragona in pigeon of Hyderabad, Sindh, Pakistan and observed significant tissue damage and morphological alteration which distressed the entire structural design of the intestine. Mehmood et al. (2019) also reported that Raillietina spp. is the most prevalent parasite in pigeons of Jammu, India.

Raillietina spp. is a zoonotic important parasite. The infection of Raillietina spp. in humans was reported by many authors in different regions i.e. Brenes et al. (1983) from Costa Rica, Rougier et al. (1981) from French Polynesia, Margono et al. (1977) from Jakarta Indonesia.

The pigeon in particular acts as a rich source of infection in the human environment (Haag-Wackernagel, 2005). There is limited information on the transfer of parasites from pigeons to humans in Pakistan. However, much research on the chance of transferring infection to human beings has been recorded in other regions of the world (HaagWackernagel, 2005; Haag-Wackernagel and Bircher, 2010). There is currently no research available to study the role of pigeons at District Lower Dir, to transmit disease through their excreta in the different food items in the open environment and contamination with droppings.

\section{CONCLUSION}

It is concluded, that a large number of Raillietina spp. are found in the studied pigeon which is the cause of emaciation, diarrhea and droopiness. Further studies are needed to find out the prevalence of this parasite in pigeons of the studied area. It is suggested to raise awareness among the populations of urban regions about the risks of contracting pigeon infection, the significance of hygiene, vaccination against zoonotic parasites and social behavior. This will assist to minimize the incidence of parasitic infestation of domesticated pigeons in humans.

\section{AUTHORS CONTRIBUTION}

All the authors contributed significantly to this manuscript.

\section{CONFLICT OF INTEREST}

The authors have declared no conflict of interest.

\section{REFERENCES}

-Adang KL, Oniye SJ, Ajanusi OJ, Ezealor AU, Abdu PA (2008). Gastrointestinal helminths of the domestic pigeons (Columba livia domestica Gmelin, 1789 Aves: Columbidae) in Zaria. Northern Nigeria. Sci. World J., 3: 33-37. https:// doi.org/10.4314/swj.v3i1.51769

-Alenyorege B, Alexander A, Kosono A, Addy S (2011). Termites as intermediate hosts for poultry worms. J. Vet. Adv., 1: 1623.

-Alkharigy FA, El-Naas AS, Maghrbi AAE (2018). Survey of parasites in domestic pigeons (Columba livia) in Tripoli, Libya. Open Vet. J., 8(4): 360-366. https://doi.org/10.4314/ ovj.v8i4.2

-Bahrami AM, Dastgheib M, Shaddel M (2015). Study of parasitic infection and its histological changes in a bird. Ann. Mil. Health Sci. Res., 13: 86-91.

- Brenes R, Hangen G, Monge E, Muñoz G, Rodríguez G, Loría $R$ (1983). Primer caso humano de parasitosis por Raillietina sp en Costa Rica. Rev. Cost. Cienc. Med., 4: 81-87.

- Butboonchoo P, Wongsawad C, Rojanapaibul A, Chai JY (2016). Morphology and molecular phylogeny of Raillietina spp. (Cestoda: Cyclophyllidea: Davaineidae) from domestic chickens in Thailand. Korean J. Parasitol., 54: 777-786. https://doi.org/10.3347/kjp.2016.54.6.777

- Cheng T (1973). General Parasitology. Academic press, New York, San-Francisco and London.

-El-Dakhly KM, El-Seify MA, Mohammed ES, Elshahawy IS, Fawy SAM, Omar MA (2019). Prevalence and distribution pattern of intestinal helminths in chicken and pigeons in Aswan, Upper Egypt. Trop. Anim. Health Pro., 51(3): 713718. https://doi.org/10.1007/s11250-018-1725-1

-Fuhrmann O (1920). Conside' rations ge' nerale' s sur les Davainea. Festschrift fu" r Zschokke, Bale, 7: 1-19. 
-Haag-Wackernagel D (2005). Parasites from feral pigeons as a health hazard for humans. Ann. Appl. Biol. 147(2): 203-210. https://doi.org/10.1111/j.1744-7348.2005.00029.x

-Haag-Wackernagel D, Bircher AJ (2010). Ectoparasites from feral pigeons affecting humans. Dermatology, 220(1): 82-92. https://doi.org/10.1159/000266039

- Hoste H (2001). Adaptive physiological processes in the host during gastrointestinal parasitism. Int. J. Parasitol., 31: 231244. https://doi.org/10.1016/S0020-7519(00)00167-3

-Kaufmann J (1996). Parasitic infections of domestic animals: A diagnostic manual. Birkhauser Verlag. Basel. Schweiz. https://doi.org/10.1007/978-3-0348-7666-7

-Khan W, Gul S, Gul M, Kamal M (2018). Prevalence of parasiticinfestation in domestic pigeons at Malakand region, Khyber Pakhtunkhwa, Pakistan. Int. J. Biosci. 12(4): 1-7. https://doi. org/10.12692/ijb/12.4.1-7

- Margono SS, Handojo I, Hadidjaja P, Mahfudin H (1977). Raillietina infection in children in Indonesia. Southeast Asian J.Trop. Med. Public Health, 8(2): 195-199.

- Mehmood S, Nashiruddullah N, Ahmed JA, Borkataki S (2019).
Parasitic affections of domesticated pigeons (Columba livia) in Jammu, India. Ann. Parasitol. 65(1): 53-64.

- Ramisz BA, Marriniak TA, Pilarczyk M, Dabrowska WM, Bakowska M (2007). Intestinal parasites of parrots. Wiad. Parazytol., 53: 129-32.

- Rougier Y, Legros F, Durand JP, Cordoliani Y (1981). Four cases of parasitic infection by Raillietina (R.) celebensis (Kanicki, 1902) in French Polynesia. Trans. R. Soc. Trop. Med. Hyg., 75(1): 121. https://doi.org/10.1016/0035-9203(81)90028-6

-Ruprah, NS, Chaudhri SS, Gupta SK (1986). Parasitological Manual-1: General parasitology and platyhelminthes. Haryana Agricultural University.

-Schmidt GD (1986). Handbook of tapeworm identification. Boca Raton, Florida, USA. CRC Press, Inc. pp. 252-266.

- Shaikh F, Ursani TJ, Naz S, Dhiloo KH, Solangi AW (2016). Histopathological changes in the intestine of infected pigeon (Columba livia) naturally infected with Helminth parasites from Hyderabad, Sindh, Pakistan. Sci. Int., 6: 5273-5275.

-Soulsby EJL (1982). Helminths, arthropods and protozoa of domesticated animals. $7^{\text {th }}$ edition Bailliere tindall, London. 